\title{
Sosiaalinen tuki työssä: Katsaus 2000-Iuvun tutkimuskirjallisuuteen
}

\author{
Leena Mikkola
}

\section{Tiivistelmä}

Sosiaalinen tuki on vuorovaikutusta, joka auttaa hallitsemaan kuormittavaan tilanteeseen liittyvää epävarmuutta ja vahvistaa yksilön käsitystä hyväksytyksi tulemisesta ja elämänhallinnasta. Sen on todettu selittävän työssäjaksamista, ja sillä on yhteyttä myös työmotivaatioon ja työyhteisöön sitoutumiseen. Tämän artikkelin tavoitteena on osoittaa, millä tavoin sosiaalista tukea työyhteisöissä on tutkittu ja mitä sosiaalisesta tuesta tällä hetkellä tiedetään kansainvälisen tutkimuskirjallisuuden perusteella. Artikkeli perustuu systemaattiseen kirjallisuuskatsaukseen, tarkastelu rajattiin 2000-luvulla julkaistuun empiiriseen puheviestinnän tutkimukseen. Aineiston analyysissä tarkasteltiin tutkimusten ongelmanasettelua, sosiaalisen tuen teoreettista ja operationaalista määrittelyä, tutkimusmenetelmiä ja aineistoja.

Tarkasteltavana olleet tutkimukset jäsentyivät ongelmanasettelultaan neljään ryhmään: 1) yksilön kuormitusta, työuupumusta ja selviytymistä, 2) organisaatioon identifioitumista, tyytyväisyyttä ja tuloksellisuutta, 3) sosiaalista tukea ja ammatillisen roolin rakentumista sekä 4) tuen tarvetta, saamista ja osoittamista kuvaaviin ja selittäviin tutkimuksiin. Tutkimuksista puolet oli toteutettu kvantitatiivisilla menetelmillä, puolet laadullisesti tai menetelmätriangulaatiota käyttäen. Sosiaalisen tuen rooli tutkimuksissa on lähinnä selittävä. Sen avulla on pyritty ymmärtämään sekä yksilön työroolia, ammatti-identiteettiä ja siihen liittyvää kuormittumista että yksilön suhdetta työorganisaatioonsa. Interpersonaalisella tasolla sosiaalista tukea on tarkasteltu johtajalta ja työtovereilta saatuna sosiaalisena tukena, organisaatiotasolla tukea on kuvattu supportiivisen viestintäilmapiirin ja organisaation havaitun supportiivisuuden käsitteillä. Tulevaisuudessa näiden käsitteiden välisiä yhteyksiä tulisi selvittää. Tutkimushaasteena on myös työn kontekstiin sopivien supportiivisen viestinnän analyysimenetelmien kehittäminen.

Asiasanat: organisaation koettu supportiivisuus, organisaatioon identifioituminen, sosiaalinen tuki, supportiivinen viestintä, työyhteisö, työuupumus 


\section{Johdanto}

Sosiaalinen tuki on vuorovaikutusta, joka auttaa hallitsemaan kuormittavaan tilanteeseen liittyvää epävarmuutta ja vahvistaa yksilön käsitystä hyväksytyksi tulemisesta ja elämänhallinnasta (Albrecht \& Adelman 1987, 19; Albrecht \& Goldsmith 2003, 265; Mikkola 2006, 30). Tuella on todettu olevan voimakas yhteys yksilön hyvinvointiin, minkä vuoksi sitä on tutkittu runsaasti. Jo varhain tutkijat kiinnostuivat myös työhön liittyvän kuormituksen yhteydestä sosiaaliseen tukeen (Albrecht \& Adelman 1984). Työssä saatavan ja saatavilla olevan tuen on todettu olevan yhteydessä muun muassa työperäiseen stressiin, työuupumukseen, työhön sitoutumiseen ja työmotivaatioon (esim. Ellis \& Miller 1994).

Puheviestinnän alalla on 2000-luvulla ilmestynyt runsaasti tutkimuksia sosiaalisesta tuesta. Niissä on tarkasteltu esimerkiksi tuen antajan motivaatiota, supportiivisten sanomien arviointia ja tuen ja hyvinvoinnin välisiä yhteyksiä (Albrecht \& Goldsmith 2003; Bodie \& Burleson 2008; Burleson \& MacGeorge 2002). Sosiaalisen tuen käsitteen rinnalla on käytetty supportiivisen viestinnän käsitettä, jonka voidaan ymmärtää kuvaavan tukea viestintäkäyttäytymisen tasolla. Tutkimuksissa supportiivista viestintää on tutkittu erityisesti supportiivisten sanomien ja ilmausten näkökulmasta (Burleson \& MacGeorge 2002). Tukea on tarkasteltu myös organisaation koettuna supportiivisuutena, jolla viitataan yksilön kokemukseen siitä, että organisaatio arvostaa työntekijän panosta ja välittää tämän hyvinvoinnista (Eisenberg, Huntington, Hutchinson \& Sowa 1986). Puheviestinnän alalla on viime vuosina tutkittu melko runsaasti myös stressin, erityisesti roolistressin, hallinnan ja sosiaalisen tuen välisiä yhteyksiä (Apker \& Ray 2003). Alalla ei kuitenkaan ole esitetty systemaattisia katsauksia, joissa olisi laajalti tarkasteltu ja arvioitu työyhteisön sosiaaliseen tukeen kohdentuvien tutkimusten tutkimusongelmia, -menetelmiä ja -tuloksia.

Tämän artikkelin tavoitteena on osoittaa, millä tavoin sosiaalista tukea työyhteisöissä on tutkittu 2000-luvulla ja mitä sosiaalisesta tuesta tällä hetkellä tiedetään kansainvälisen tutkimuskirjallisuuden perusteella. Tarkastelu kohdentuu 2000-luvulla julkaistuun empiiriseen tutkimukseen. Artikkelissa kuvataan ensin tämän katsauksen tutkimusmenetelmä ja -aineisto. Sen jälkeen kuvataan aineistona olevien tutkimusten ongelmanasettelua, menetelmiä ja aineistoja ja kootaan tutkimusten keskeiset tulokset. Lopuksi pyritään luonnehtimaan tutkimushaasteita 2010-luvulle.

\section{Tutkimusmenetelmä ja -aineisto}

Tiedonhaku, aineiston käsitteleminen ja analyysi. Artikkeli perustuu systemaattiseen kirjallisuuskatsaukseen kansainvälisestä empiirisestä tutkimuskirjallisuudesta. Kirjallisuushaku tehtiin EBSCO Host Communication and Mass Media Complete -tietokannasta, jossa ovat keskeisimmät viestintätieteiden alan 
julkaisut. Tiedonhaku rajattiin aikavälille 1.1.2000-15.6.2009 ja suoritettiin Jyväskylän yliopiston tiedonhakuportaali Nellin kautta. Haku tehtiin sanahakuina yhdistelmillä "social support and workplace" (240 viitettä), "supportive communication and workplace" (47 viitettä), "supportive communication and organization" (84 viitettä) ja "supportive interaction and workplace" (4 viitettä). Sanahaku valittiin tiedonhakuun asiasanojen sijaan, jotta voitiin varmistaa haun kattavuus: vaikka artikkelissa kuvattaisiin ja käsiteltäisiin sosiaalista tukea jossain muodossa, käsitteet eivät välttämättä esiinny asiasanoina.

Hakutulosten käsittely aloitettiin käymällä läpi kaikki 375 viitettä. Jatkokäsittelyyn poimittiin ne artikkelit, joiden tiivistelmissä tai asiasanoissa mainittiin sosiaalinen tuki tai sen eri muodot, kuten emotionaalinen, instrumentaalinen ja tiedollinen tuki, ja joissa tutkimus kohdentui työyhteisöön, työpaikan vuorovaikutussuhteisiin, työorganisaatioon tai ammattiin liittyvään viestintään. Mukaan otettiin tutkimukset, joiden tiivistelmässä tai asiasanoissa mainittiin organisaation koettu supportiivisuus, koska sen yhtenä ulottuvuutena voidaan pitää johdolta saatua tukea. Koska tavoitteena on kuvata empiiristä tutkimusta, aineistosta karsittiin katsausartikkelit ja kirjallisuusarvostelut, joissa ei esitelty ensikäden tutkimustietoa. Myös hakutuloksissa olleet monografiat karsiutuivat tämän kriteerin perusteella. Jäljelle jääneet tekstit olivat tieteellisissä aikakauslehdissä julkaistuja empiirisiä tutkimusartikkeleita ja tutkimusta esitteleviä kongressiesitelmiä, myöhemmin molempiin viitataan tässä tekstissä käsitteellä artikkeli.

Hakusanoilla "supportive communication and workplace" sopivia artikkeleita löytyi 9 ja hakusanoilla "social support and workplace" 23 artikkelia. Näistä päällekkäisiä osumia oli 8. Hakusanoilla "supportive communication and organization" löytyi 8 artikkelia, mutta 7 niistä oli päällekkäisiä aikaisempien osumien kanssa, joten rajauksen jälkeen tarkastelussa oli mukana 25 artikkelia, jotka luettiin läpi. Lukemisen perusteella pudotettiin pois yksi artikkeli, koska osoittautui, että tutkimuksessa tarkasteltiin opettajien sijaan ainoastaan opiskelijoita, eikä artikkeli näin täyttänyt työyhteisö-kriteeriä. Lopullisen aineiston muodosti 24 artikkelia, joista 12 oli aikakauslehdessä julkaistuja tutkimuksia ja 12 kansainvälisissä kongresseissa pidettyjä tieteellisiä esitelmiä.

Analyysi aloitettiin poimimalla artikkeleista niissä kuvattu tutkimustehtävä ja tutkimuskysymykset ja mahdolliset hypoteesit. Samalla koottiin tieto, millaisena teoreettisena ilmiönä ja empiirisenä käsitteenä sosiaalista tukea on tarkasteltu. Tutkimusten tavoitteiden perusteella artikkelit luokiteltiin aineistolähtöisesti neljään luokkaan: 1) yksilön kuormitusta, työperäistä stressiä, työuupumusta ja selviytymistä kuvaaviin ja selittäviin tutkimuksiin, 2) organisaatioon identifioitumista, tyytyväisyyttä ja tuloksellisuutta kuvaaviin ja selittäviin tutkimuksiin, 3) sosiaalista tukea ammatillisen roolin näkökulmasta kuvaaviin tutkimuksiin ja 4) tutkimuksiin, joissa kuvattiin tuen tarvetta, osoittamista ja saamista työyhteisössä tai työhön liittyvissä suhteissa. 
Analyysin toisessa vaiheessa poimittiin tutkimusten menetelmäkuvaukset, joiden perusteella artikkelit luokiteltiin 1) laadullisiin ja 2) määrällisiin sekä 3) laadullisen ja määrällisen menetelmän triangulaatioon perustuviin tutkimuksiin. Samalla koottiin tiedot tutkimusten osallistujista ja aineistokoosta ja tarkasteltiin, onko kyseessä poikkileikkaus- vai tapaustutkimus. Lisäksi poimittiin tiedot pääasiallisesta analyysimenetelmästä. Laadullisen tutkimuksen kriteerinä pidettiin aineistonkeruutapaa, vaikka aineistoa olisikin tutkimuksessa kvantifioitu. Kolmannessa vaiheessa aineistoa tarkasteltiin tutkimustulosten näkökulmasta ja koottiin sosiaalista tukea kuvaavat päätulokset. Ne luokiteltiin aineistolähtöisesti kahteen luokkaan: 1) yksilön työroolia, ammatti-identiteettiä ja siihen liittyvää kuormittumista kuvaaviin tuloksiin sekä 2) yhteisöllisyyttä ja yksilön suhdetta omaan työorganisaatioonsa kuvaaviin tuloksiin.

Tutkimuksen kattavuus ja analyysin haasteet. Katsauksen lähestymistavaksi valittiin systemaattinen kirjallisuuskatsaus, jonka luotettavuus perustuu erityisesti tiedonhankinnan rajaukseen ja huolellisuuteen. Koska tavoitteena oli kuvata nimenomaan viestintätieteellistä tutkimusta, tietokannaksi valittiin CMMC-tietokanta. Tiedonhaun ja aineistoon poimittujen lähteiden osalta kriteerit määriteltiin tarkasti, viitteet käytiin läpi systemaattisesti ja tiedonhaun suorittamisessa käytettiin informaatikon tukea. Kattavuuden ja rajauksen osalta on kuitenkin syytä huomioida aineiston rajoitukset: Tavoitteesta huolimatta katsauksen tulokset eivät rajaudu vain viestintätieteisiin, koska tietokannassa on myös lähialojen kirjallisuutta. Toisaalta on mahdollista, että katsauksen ulkopuolelle jää joitakin aiheen kannalta relevantteja lähteitä, koska kaikki alan tutkimuskirjallisuus ei välttämättä ole valitussa tietokannassa. Tietokannan valintaa voi kuitenkin pitää perusteltuna, koska siinä ovat mukana alan keskeiset julkaisut ja tiedonhaku tuottaa osumia kaikista alan tärkeimmistä kongresseista.

Aineiston analyysi pyrittiin suorittamaan systemaattisesti ja vaiheittain. Tutkimustehtävät ja tutkimustulokset luokiteltiin aineistolähtöisesti, menetelmät puolestaan valmiin kategorisoinnin perusteella. Analyysin haasteet kytkeytyivät aineistolähtöisten luokkien luomiseen. Tutkimustehtävien osalta aineistosta erottuivat melko helposti omiksi luokikseen yksilön kuormitukseen liittyvät ja organisaatioon ja työhön suhtautumista selittävät tutkimukset. Yksi tutkimuksista (Singh 2000) olisi ollut mahdollista sijoittaa kumpaankin luokkaan, ratkaisu perustui kuitenkin tuen kannalta keskeisimpään muuttujaan eli työperäiseen stressiin. Kolmannen ja neljännen luokan muodostaminen oli haastavampaa, koska tutkimukset eivät muodostaneet yhtä koherentteja teemoja kuin kaksi ensimmäistä ryhmää ja aineiston pienuus korosti tutkimusten näkökulmaeroja. Lopulta luokittelukriteereiksi muodostuivat roolin ja ammatti-identiteetin merkitys, jonka perustalle rakennettiin kolmas luokka, ja tukeen liittyvä viestintäkäyttäytyminen, jonka perusteella ryhmiteltiin omaksi luokakseen tuen tarpeeseen, osoittamiseen ja saamiseen liittyvät artikkelit. Tutkimustehtävien perusteella tehdyn luokittelun haasteena olivat erityisesti ne artikkelit, joissa 
tuen käsite ei ollut osa tutkimuksen ongelmanasettelua vaan nousi esille aineistosta tai oli osa käytettyä mittaria. Näissä tapauksissa luokitteluperusteena käytettiin tuen ja tutkimuksen muiden käsitteiden yhteyttä. Tutkimustulosten luokitteleminen oli haastavaa: vaikka kahden pääluokan kriteerit syntyivät aineiston pohjalta melko helposti, muutaman kuvailevan tutkimuksen kiinnittyminen pääluokkiin jäi löyhäksi. Ne täyttivät kuitenkin riittävissä määrin kriteerit tuen yksilöllisestä tai organisaatioon liittyvästä merkityksestä.

Analyysin tulokset pyrittiin varmentamaan siten, että aineisto luokiteltiin tutkimustehtävien, -menetelmien ja -tulosten osalta kahteen kertaan muutaman viikon väliajalla. Jotta lukija voi arvioida analyysin onnistumista ja sen luotettavuutta, aineistona olleiden tutkimusten tutkimustehtävät ja -menetelmäkuvaukset on koottu liitteinä oleviin taulukoihin 1 ja 2 .

\section{Työyhteisöjen sosiaalinen tuki tutkimuskohteena}

Sosiaalinen tuki työn kontekstissa näyttäytyy moninaisena tutkimuskohteena. Sitä on tarkasteltu useiden erilaisten ilmiöiden yhteydessä, eri määritelmiin perustuen ja monin eri tavoin operationaalistamalla. Liitteenä olevassa taulukossa 1 on jäsennetty kunkin tutkimuksen päätavoitteen mukaan tutkimustehtävät ja ne teoreettiset ja/tai empiiriset valinnat, jotka luonnehtivat sosiaalisen tuen roolia tutkimuksessa. Kunkin artikkelin vuosiluvun perässä oleva tunniste ilmaisee, millaisesta artikkelista on kyse ( $\mathrm{A}=$ aikakauslehdessä julkaistu artikkeli, E = kongressiesitelmä).

Yksilön kuormitusta, työuupumusta ja selviytymistä kuvaava ja selittävä tutkimus. Tutkimuksista kahdeksassa päätehtävänä oli tarkastella sosiaalisen tuen yhteyksiä työperäiseen kuormitukseen, stressiin, työuupumukseen tai selviytymiseen. Zhangin ja Zhun (2007) tutkimuksessa mitattiin kiinalaisten opettajien kokemaa työperäistä stressiä ja työuupumusta sekä näiden yhteyttä johtajalta, työtovereilta ja läheisiltä saatuun emotionaaliseen, tiedolliseen ja välineelliseen tukeen. Sand ja Miyazaki (2000) tarkastelivat myyntihenkilöstön työuupumuksen ja tukiverkostojen välistä yhteyttä, erityisesti sosiaalisen tuen yhteyksiä työuupumuksen eri ulottuvuuksiin. Tukea tarkasteltiin muun muassa ohjauksena ja esimieheltä saatuna emotionaalisena tukena. Singh (2000) puolestaan kuvasi johtajalta saadun sosiaalisen tuen ja tehtävään liittyvän hallinnan välittömiä ja välillisiä vaikutuksia stressiin ja työuupumukseen, tuottavuuteen, työn laatuun ja organisaatioon sitoutumiseen asiakaspalvelutyössä. Tukea mitattiin käsityksinä siitä, kuinka johtaja tunnistaa työntekijän ponnistelut, kuinka reilusti työntekijä kokee johtajan kohtelevan häntä ja kuinka supportiiviseksi johtaja koetaan.

Greenberg, Thomas, Murphy ja Dandeker (2003) kartoittivat tekijöitä, jotka ovat yhteydessä Irakissa työskennelleen mediahenkilöstön työperäiseen stressiin ja työtyytyväisyyteen. Laadullisessa tutkimuksessa tarkasteltiin työnanta- 
jan vaatimuksia, päätöksenteon mahdollisuuksia ja sosiaalista tukea. Hoevenin ja De Jongin (2006) tavoitteena oli selvittää, miten työn piirteet, yksilötekijät, organisaation viestintä ja organisaatioon kiinnittyminen selittävät rahoituskonsulttien työuupumusta. Johtajalta ja työtovereilta saatu sosiaalinen tuki oli yksi tutkimuksessa tarkastelluista viestintätekijöistä, lisäksi mitattiin tiedon yli- ja alikuormitusta, viestintätyytyväisyyttä ja -ilmapiiriä. Roloff ja Brown (2006) tutkivat, toimivatko organisaation havaittu supportiivisuus ja kokemus psykologisen sopimuksen noudattamisesta puskureina vapaaehtoisen ylityön ja työuupumuksen välillä. Tuki määriteltiin sellaisen epävarmuuden vähentämiseksi, joka kohdistuu työntekijän käsitykseen siitä, missä määrin häntä arvostetaan työntekijänä.

Sosiaalista tukea on tarkasteltu myös selviytymisstrategioiden näkökulmasta. Omdahl ja Fritz (2006) tutkivat työpaikan negatiivisten suhteiden vaikutusta stressiin ja työuupumukseen. He tarkastelivat, millaiset selviytymisstrategiat ovat tehokkaita ehkäisemään ongelmallisista vuorovaikutussuhteista johtuvaa työuupumusta. Sosiaalisen tuen hakeminen oli yksi näistä strategioista. Krouse ja Afifi (2007) selvittivät, millaisia viestintäkeinoja hoitotyötä tekevät naiset käyttävät selviytyäkseen perheestä aiheutuvan stressin siirtymisestä työpaikalle. Tutkimuksessa kuvattiin koettuja stressitekijöitä, selviytymisstrategioita ja organisaatioon liittyviä supportiivista viestintää edistäviä tekijöitä.

Organisaatioon identifioitumista, tyytyväisyyttä ja tuloksellisuutta selittävä ja kuvaava tutkimus. Kahdeksassa tutkimuksessa päätavoitteena oli selittää yksilön työpaikkaan kohdistuvia käsityksiä ja asenteita kuten identifioitumista ja työtyytyväisyyttä sekä työn tuloksellisuutta. Meyers ja Hearn (2007) tutkivat, mitkä viestintäilmiöt koetaan keskeiseksi etätyössä ja mitkä niistä ennustavat etätyön itsearvioitua tuloksellisuutta. Johdolta ja työtovereilta saatu tuki oli yksi merkitykselliseksi koetuista ilmiöistä. Tutkimuksessa arvioitiin tyytyväisyyttä tukeen ja tuen yhteyttä tuloksellisuuteen. Gibson ja Gibbs (2005) tarkastelivat virtuaalitiimejä ja niiden innovatiivisuuteen potentiaalisesti vaikuttavia tekijöitä, kuten kansallista diversiteettiä, maantieteellistä hajautuneisuutta ja riippuvuutta viestintäteknologian käytöstä. Tukea tarkasteltiin supportiivisena viestintäilmastona, jonka tutkijat arvelivat vähentävän muiden tekijöiden negatiivisia vaikutuksia.

Fay ja Kline (2008) pyrkivät kuvaamaan informaalisen vuorovaikutuksen merkitystä etätyöntekijöiden organisaatioon identifioitumiselle. Supportiiviset sanomat olivat yksi tutkimuksessa tarkastelluista informaalisen vuorovaikutuksen muodoista. Roloff ja Fonner (2005) tutkivat, millä tavoin vanhempien ja ystävien kanssa työstä puhuminen vaikuttaa työelämään tulevien nuorten käsityksiin tulevasta työpaikasta, organisaation supportiivisuudesta ja työturvallisuuden ja luottamuksen kokemisesta. Tutkimuksessa tarkasteltiin erityisesti emotionaalista tukea. 
Steinheider, Wuestewald ja Bayerl (2006) tutkivat osallistuvan johtamisen mallin käyttöönottoa poliisilaitoksella. Tutkimuksessa kysyttiin, kehittääkö uusi malli työntekijä-johtajasuhteita poliisiorganisaatiossa ja lisääkö se organisaation koettua supportiivisuutta ja organisaatioon sitoutumista. Czech ja Forward (2007) tarkastelivat yliopiston laitosjohtajan viestintäkäyttäytymistä, jota tutkimuksessa kuvattiin sellaisilla supportiivisen ilmapiirin ulottuvuuksilla kuin tasavertaisuus, ongelmakeskeisyys ja spontaanisuus. Tutkijat pyrkivät selvittämään, miten johtajan viestintäkäyttäytyminen on yhteydessä työntekijöiden käsityksiin tehokkuudesta, johtamistyylistä, työtyytyväisyydestä ja tyytyväisyydestä johtaja-työntekijäsuhteessa.

Organisaation näkökulmasta sosiaalista tukea on lähestytty erityisesti organisaatioon liittyvien kognitioiden ja työn tuloksia selittävänä tekijänä. Analyysissä tähän luokkaan sijoittuivat myös tutkimukset, joissa sosiaalisen tuen merkitys yhteisöllisyydelle ja sen rakentumiselle nousevat esille tutkimuksen tuloksissa ja menetelmissä. Gómez (2009) tarkasteli sosiaalista tukea yhtenä organisaatioon sosiaalistumista kuvaavana faktorina. Gilliganin (2005) lehdistöhuoneen toimijoiden kilpailua ja yhteistyötä tarkastelleessa tutkimuksessa sosiaalinen tuki nousi esille aineiston analyysissä.

Ammatillisen roolin rakentumista kuvaava tutkimus. Neljässä tähän aineistoon valikoituneessa tutkimuksessa keskeisenä tutkimuskohteena oli yksilön ammatti-identiteetti ja siihen liittyvät roolikysymykset. Schmisseurin (2003) tavoitteena oli selittää, millä tavoin rooli-identiteetistä ja organisaatioon identifioitumisesta rakentuva sosiaalinen identiteetti ja sosiaalinen tuki toimivat välittäjänä emotionaalisen dissonanssin ja työhyvinvoinnin välillä. Tukea Schmisseur tarkasteli johtajalta ja kollegoilta haettuna ja pyytämättä saatuna tukena. Forward (2000) kuvasi tutkimuksessaan seurakuntapastoreiden kokeman stressin määrää ja muotoa sekä pappien roolia suhteessa seurakuntaansa. Forward selvitti, millaiset tilanteet ovat kuormittavia ja auttavatko roolia kuvaavat metaforat ymmärtämään tilanteiden koettua kuormittavuutta. Sosiaalinen tuki nähtiin epävarmuuden hallintana, joka puolestaan liittyy tarpeeseen vahvistaa omaa ammatillista roolia.

Kleinman (2000) tutki teknisellä alalla työskentelevien naisten identifioitumista internetissä toimivaan keskusteluryhmään ja ryhmän merkitystä sosiaalisen tuen lähteenä. Hän pyrki selvittämään, miksi osallistujat liittyvät ryhmiin, millaisia viestejä naiset lähettävät ryhmään ja millaista hyötyä he kokevat saavansa ryhmästä. Hullettin, McMillanin ja Roganin (2000) tutkimuksessa selvitettiin hoivakodissa työskentelevien hoitajien kokemia rooliristiriitoja ja niiden vaikutuksia työuupumukseen. Rooliristiriitojen lähteenä oli hoitajan oman käsityksen ja organisaation odotusten välinen ero, joka koski asukkaalle annettavan tuen muotojen ensisijaisuutta.

Tuen tarvetta, saamista ja osoittamista kuvaava tutkimus. Tämän katsauksen tutkimuksista neljä oli sellaisia, joissa keskeinen tutkimustehtävä koh- 
dentui työssä saatavan tai annettavan tuen tarpeeseen, muotoihin ja lähteisiin tai joissa nämä teemat nousivat esiin nimenomaan aineistosta. Amason, Allen ja Holmes (1999) tutkivat Yhdysvalloissa työskenteleviä latino- ja anglo-amerikkalaistaustaisia tehdastyöntekijöitä ja selvittivät, kuinka paljon he saavat emotionaalista, tiedollista ja välineellistä tukea ja arviointitukea eri lähteistä. Lisäksi tarkasteltiin tuen yhteyttä latinotaustaisten työntekijöiden akkulturatiiviseen stressiin. Kulttuurin viitekehys oli myös Sayakcin (2007) tutkimuksessa, jossa hän kartoitti ulkomaalaistaustaisten Yhdysvalloissa toimivien college-opettajien kokemia viestintähaasteita ja mahdollisuuksia uuteen kulttuuriin sopeutumisessa. Sosiaalinen tuki nousi aineistosta esille yhtenä sopeutumiseen liittyvänä haasteena.

Hopkins (2001) tutki keskijohdon ylemmältä johdolta hakemaa ja saamaa tukea. Hän pyrki selvittämään, hakeeko keskijohto tukea henkilökohtaisiin ongelmiinsa ensisijaisesti henkilökohtaisista lähteistä ja onko ylempi johto halukkaampi tarjoamaan epämuodollista tukea kuin ohjaamaan muodollisen avun pariin. Tutkimuksessa tarkasteltiin myös, selittävätkö keskijohdon käsitykset ylemmältä johdolta saadusta tuesta sitä, miten usein keskijohto lähestyy johtajia ongelmatilanteissa.

Binghamin ja Batteyn (2005) tavoitteena oli kuvata professoreiden työssään osoittamaa tukea. Tutkimuksessa tarkasteltiin supportiivisia responsseja eli sitä, millä tavoin professori osoittaisi tukea, mikäli opiskelija kertoisi seksuaalisesta häirinnästä. Tutkimuksessa kuvattiin tuen muotoa, tuen antajan ja saajan sukupuolen yhteyttä supportiiviseen käyttäytymiseen ja käsityksiä tilanteen haastavuudesta ja uhrin kuormituksen määrästä. Supportiivista viestintää analysoitiin tutkimuksessa lohdutus- ja ratkaisukeskeisinä sanomina.

Sosiaaliseen tukeen liittyvät konstruktiot ja empiiriset valinnat. Aineistoa on mahdollista tarkastella paitsi tutkimustehtävien myös sosiaalisen tuen määrittelemisen ja operationaalisten käsitteiden kautta. Niissä tutkimuksissa, joissa sosiaalinen tuki on määritelty teoreettisena käsitteenä interpersonaalisella tasolla, tuki nähdään lähinnä epävarmuuden hallintana. Yhdessä tutkimuksessa tuki määritellään selviytymisresurssiksi. Tuen tarkastelunäkökulmana on ollut myös niin sanottu organisaation koettu supportiivisuus, joka viittaa tukeen yksilön ja organisaation välisessä suhteessa. Lisäksi tukea on tarkasteltu supportiivisena viestintäilmastona (ks. Gibb 1961), jonka piirteet on yhdessä tutkimuksessa operationaalistettu kuvaamaan johtajan viestintäkäyttäytymistä.

Kahdeksassa tutkimuksessa tarkastellaan sosiaalista tukea työtovereilta saatuna tukena, yhdeksässä tutkimuksessa johtajalta saatuna tukena. Johtaja nähdään näissä tutkimuksissa tuen lähteenä, ainoastaan yhdessä tutkimuksessa tarkastellaan johtajan saamaa tukea. Kolmessa tutkimuksessa tuen lähteenä tarkastellaan perhettä ja muita läheisiä. Supportiivisiksi sanomiksi sosiaalinen tuki on määritelty kahdessa tutkimuksessa, lisäksi kahdessa tutkimuksessa tukeen viitataan supportiivisen käyttäytymisen käsitteellä. Kahdessa tutkimuksessa 
tukea lähestytään selviytymisstrategioiden näkökulmasta. Tuen muotoina tutkimuksissa kuvataan tiedollista, välineellistä, emotionaalista, käytännöllistä ja taloudellista tukea, tukea suhteiden ylläpitämisenä ja ohjaamisena sekä tukea arviointiapuna. Laadullisissa tutkimuksissa tukea on tarkasteltu aineistolähtöisesti luokitellen. Tuki kytkeytyy näissä sekä ammatillisen roolin rakentumiseen että yhteisöllisyyden ylläpitämiseen.

\section{Sosiaalisen tuen tutkimusmenetelmät ja tutkimusten aineistot}

Aineiston analyysissä tutkimukset jäsennettiin tutkimusmenetelmän perusteella laadullisiin, määrällisiin ja näiden triangulaatiota hyödyntäviin tutkimuksiin. Lisäksi tutkimukset jaettiin tapaus- ja poikkileikkaustutkimuksiin. Liitteenä olevaan taulukkoon 2 on koottu tukea käsittävät aineistonkeruumenetelmät, tutkimushenkilöt, pääasialliset analyysimenetelmät ja tutkimustyyppi: tutkimuksista kolme täytti tapaustutkimuksen kriteerit, muut olivat luonteeltaan poikkileikkaustutkimuksia.

Tarkasteltavana olleista 24 tutkimuksesta 12 oli toteutettu kokonaan kvantitatiivisilla menetelmillä. Näissä kaikissa aineisto oli koottu kyselyllä. Sosiaalista tukea mitattaessa käytettiin seitsemässä tutkimuksessa kysymystyyppinä Likert-väittämiä. Valmiista mittareista sovellettiin kahdessa tutkimuksessa organisaation koetun supportiivisuuden mittaria, yhdessä tutkimuksessa sosiaalisen tuen mittaria (Social Support Scale) ja yhdessä sosiaalisen tuen muotoja kuvaavaa mittaria (Social Support Behavior Scale). Sosiaalinen tuki on tutkimuksissa lähinnä selittävänä muuttujana. Kahdeksassa tutkimuksessa pääasiallinen analyysimenetelmä oli regressioanalyysi, lisäksi kvantitatiivisiin aineistoihin sovellettiin korrelaatioanalyysiä, faktorianalyysiä, polkuanalyysiä ja t-testiä.

Kokonaan laadullisilla menetelmillä oli toteutettu kuusi tutkimusta, joista neljä oli haastattelututkimuksia. Kahdessa tutkimuksessa haastatteluihin oli yhdistetty muita aineistonkeruutapoja kuten arkistoaineiston analyysiä, osallistuvaa havainnointia ja verkkokeskusteluiden analyysiä. Laadullisissa tutkimuksissa analyysimenetelmät perustuivat aineistolähtöiseen tai teoriasidonnaiseen sisällönanalyysiin. Tiettyjä tarkkarajaisia analyysimenetelmiä ei tutkimuksissa mainittu, mutta kahdessa tutkimuksessa viitattiin Straussin ja Corbinin (1990) jatkuvan vertailun periaatteisiin. Yhdessä tutkimuksessa käytettiin myös laadullisen aineiston kvantifiointia.

Määrällisen ja laadullisen menetelmän triangulaatiota käytettiin kuudessa tutkimuksessa. Yhdessä näistä kvantitatiivinen aineisto muodostui arkistoaineistosta ja lokitiedostoista, joiden lisäksi käytettiin haastatteluaineistoa. Viidessä tutkimuksessa kyselyyn yhdistettiin haastatteluaineistoa, arkistoaineiston analyysiä, osallistuvaa havainnointia ja päiväkirja-aineistoa. Yhdessä tutkimuksessa analysoitiin kyselyn ohella tutkittavien kuvaamia kollegiaalisia keskuste- 
luja, yhdessä tutkimuksessa koottiin ärsykeaineistoon perustuvia supportiivisia responsseja.

Tarkasteltaessa tutkimushenkilöitä professioittain ja ammattialoittain näyttää siltä, että sosiaalista tukea työn kontekstissa on tutkittu ennen muuta tietotyössä ja erilaisissa vuorovaikutusammateissa. Perinteisistä professioista on tutkittu erityisesti opetushenkilökuntaa, yhteensä kahdeksan tutkimuksista sijoittui koulu- ja yliopisto-organisaatioihin. Muista professioista on tutkittu poliiseja, sairaanhoitajia ja muita hoitoalalla työskenteleviä, toimittajia ja mediahenkilökuntaa sekä pappeja. Asiakaspalvelusektorilla on tarkasteltu myyntihenkilökuntaa, rahoitusneuvojia ja puhelinneuvojia ja -laskuttajia. Lisäksi on tutkittu tietotyötä tekeviä asiantuntijoita eri sektoreilla ja erilaisissa organisaatioissa. Teollisuussektorille sijoittui ainoastaan kaksi tutkimusta, joista toisessa tarkasteltiin työntekijöitä ja toisessa teollisuudessa toimivia johtajia. Organisaatiotyypin mukaisesti tutkimukset ovat kohdistuneet sekä perinteisiin että hajautettuihin organisaatioihin, ja tutkimuksissa on tarkasteltu sekä kasvokkaista että tietokonevälitteistä vuorovaikutusta.

\section{Sosiaalisen tuen merkitys yksilölle ja organisaatiolle}

Aineiston analyysissä tutkimusten tulokset luokiteltiin kahteen aineistolähtöiseen luokkaan, joista ensimmäiseen sijoittuivat yksilön kuormitusta ja yksilön ammatillista roolia selittävät ja kuvaavat tutkimukset. Toiseen luokkaan sijoittuivat yksilön ja organisaation välistä suhdetta ja työyhteisön yhteisöllisyyttä kuvaavat tutkimukset.

Tuen merkitys yksilön kuormittumiselle ja ammatilliselle identiteetille. Yksilön työperäistä kuormitusta, stressiä, työuupumusta ja selviytymistä tarkastelleet tutkimukset osoittavat, että sosiaalisella tuella, erityisesti johtajalta saadulla tuella, on merkitystä työperäisen kuormituksen hallinnalle. Zhangin ja Zhun (2007) tulosten mukaan kiinalaiset opettajat saavat tukea enemmän perheeltään ja ystäviltään kuin kollegoiltaan ja johtajaltaan, mutta johtajan osoittama tuki näyttää kuitenkin olevan tehokkainta stressin lieventämisessä, emotionaalisen uupumuksen ehkäisemisessä ja laskeneen suoriutumistason hallinnassa. Myös Greenbergin, Thomasin, Murphyn ja Dandekerin (2003) tulosten perusteella juuri työyhteisön ja työnantajan tuki oli merkityksellistä haastavan työtehtävän hallinnassa. Roloffin ja Brownin (2006) tulosten mukaan työntekijän organisaatiostaan saama palaute ja arvostus toimivat puskurina vapaaehtoisen ylityön ja työuupumuksen välillä. Sandin ja Miyazakin (2000) tulokset osoittivat työyhteisöstä saadun tuen tehokkaammaksi työuupumuksen suojaamisessa kuin kotoa saadun tuen, kotoa saadulla tuella oli heidän tutkimuksessaan jopa positiivinen yhteys stressin tasoon. Toisaalta Zhangin ja Zhun (2007) tulosten mukaan läheisiltä saatu tuki suojaa tehokkaasti uupumukseen liittyvältä depersonalisaation tunteelta. 
Koska johtajalta saadulla tuella näyttää olevan tärkeä merkitys työn kuormituksen hallinnalle, on kiinnostavaa tarkastella, millä tavoin johtajalta haetaan tukea ja millaiset tekijät siihen vaikuttavat. Hopkinsin (2001) tulosten mukaan keskijohdon odotukset ylemmän johdon tuesta ovat yhteydessä keskijohtajien halukkuuteen hakea apua johtajiltaan ongelmatilanteissa. Keskijohto kuitenkin pyrkii hakemaan tukea henkilökohtaisiin ongelmiinsa pikemminkin työpaikan ulkopuolisista kuin muodollisista lähteistä. Ylempi johto näyttäisi myös mieluummin tarjoavan epämuodollista tukea kuin ohjaavan keskijohtajia erilaisen muodollisen avun piiriin. Bingham ja Battey (2005) tarkastelivat tuen osoittamista professori-opiskelijasuhteessa ja heidän tuloksensa osoittivat, että tuen osoittaminen koettiin sitä haastavammaksi, mitä kuormittavammaksi tuen tarvitsijan tilanne arvioitiin. Tilanteen kuormittavuus ei kuitenkaan vaikuttanut siihen tapaan, jolla tukea kuvattiin osoitettavan.

Vaikka sosiaalisella tuella on positiivinen yhteys kuormituksen hallintaan, se ei välttämättä ole tehokkain selviytymiskeino kuormittavasta tilanteesta. Omdahlin ja Fritzin (2006) tulosten mukaan sosiaalisen tuen hakeminen ei ole merkitsevästi yhteydessä selviytymiseen. Sen sijaan työyhteisön ongelmallisista suhteista syntyvän kuormituksen hallinnassa ongelmanratkaisu ja uudelleenarvioiminen toimivat tehokkaina selviytymisstrategioina. Hoevenin ja De Jongin (2006) tutkimuksessa havaittiin, että sitoutumattomuus organisaatioon ennusti työuupumusta vahvemmin kuin sosiaalisen tuen määrä. Singhin (2000) tutkimuksessa työntekijän mahdollisuus vaikuttaa työtehtäväänsä oli merkitsevämpi tekijä työuupumuksen ehkäisemisessä kuin johtajalta saatu tuki.

Krouse ja Afifi (2007) tarkastelivat selviytymiskeinoja, joita yksilöt käyttävät ehkäistäkseen perheestä aiheutuvan stressin siirtymistä työpaikalle. Heidän tulostensa mukaansa keinoja on useita: työhön uppoutuminen, työ sosiaalisena purkautumiskanavana, tuulettaminen työtovereiden kanssa, työtovereilta saatu vahvistus ja rohkaisu, neuvojen pyytäminen kollegoilta sekä johtajilta ja työtovereilta saatu välineellinen tuki. Tutkimuksen mukaan sosiaalistumisprosessit, sosiaalisten verkostojen luominen ja organisaation taustafilosofia ovat sellaisia organisaation supportiivisuutta vahvistavia rakenteita, jotka mahdollistavat tuen toteutumisen työpaikalla. Myös Hullettin, McMillanin ja Roganin (2000) tulosten mukaan organisaation arvoperustalla on keskeinen merkitys työssäjaksamiselle ja rooliristiriitojen hallinnalle. Työntekijän ja työnantajan yhdenmukaiset odotukset työn tekemisen tavasta eli tässä tutkimuksessa siitä, millaista tukea potilaille tulisi osoittaa, näyttävät ehkäisevän emotionaalista uupumusta. Forwardin (2000) mukaan myös roolimallien löytäminen ja käyttäminen voivat huojentaa omaan rooliin ja ammatilliseen identiteettiin liittyvää kuormitusta. Kleinmanin (2000) tulokset osoittavat, että ammatilliset tietokonevälitteiset ryhmät voivat tarjota merkittävän identifioitumisen ja sosiaalisen tuen lähteen, silloin kun tuen mahdollisuudet ovat omassa työyhteisössä vähäisiä. Tekniikan alalla työskentelevien naisten virtuaaliyhteisön jäsenet hakivat 
ryhmästä informaation lisäksi sosiaalista tukea ja kokivat voimakasta yhteisöllisyyttä.

Tuen merkitys yksilön ja organisaation suhteelle. Johtamisen ja johtajan merkitys korostuu myös niissä tutkimuksissa, joissa sosiaalista tukea on tarkasteltu suhteessa sitoutumiseen ja työtyytyväisyyteen. Czechin ja Forwardin (2007) tulosten mukaan johtamisviestinnän supportiivisuudella on yhteys organisaation koettuun supportiivisuuteen, organisaatioon sitoutumiseen, työtyytyväisyyteen ja siihen, kuinka tyytyväisiä työntekijät suhdetasolla ovat. Johtajan supportiivinen viestintäkäyttäytyminen, erityisesti ongelmakeskeisyys, spontaanisuus ja neutraalisuus näyttäisivät ennustavan myös transformatiivista johtamista organisaatiossa. Steinheider, Wuestewald ja Bayerl (2006) vertasivat työntekijöiden käsityksiä organisaation koetusta supportiivisuudesta ja johtajilta saadusta tuesta ennen ja jälkeen niin sanotun osallistuvan johtamisen mallin (participative management) käyttöönottoa. Vertailun perusteella näytti siltä, että mallin käyttöönotto oli vahvistanut käsityksiä supportiivisuudesta ja se oli myös lujittanut affektiivista sitoutumista organisaatioon. Toisaalta organisaatioon sitoutumista voi vahvistaa myös työpaikan ulkopuolinen interpersonaalinen viestintä. Roloffin ja Brownin (2005) tulokset osoittivat, että vanhemmilta ja ystäviltä saatu emotionaalinen tuki keskusteltaessa työstä on positiivisessa yhteydessä odotuksiin työpaikasta, työturvallisuudesta ja organisaation supportiivisuudesta.

Gilliganin (2005) mukaan työpaikan sosiaalinen tuki on yhteydessä ennen muuta yhteisyyden rakentumiseen, missä kollegiaalisilla suhteilla ja yhteistyöllä on tärkeä merkitys. Fayn ja Klinen (2008) tulosten perusteella kollegoiden kanssa keskusteltaessa kuulumista tai ulkopuolisuutta vahvistava vuorovaikutus ja sosiaalinen tuki selittävät merkitsevästi organisaatioon identifioitumista etätyössä. Se, kuinka paljon kollegoistaan pitää, näyttää välittävän tätä yhteyttä. Gómezin (2009) mukaan organisaation rakenteet, kuten organisaation aikakäsitys, puolestaan heijastuvat sosiaalisen tuen mahdollisuuksiin ja esimerkiksi siihen, miten uusiin työntekijöihin työpaikalla suhtautudutaan. Amasonin, Allenin ja Holmesin (1999) tulokset osoittivat, että työntekijän tausta heijastuu työntekijöiden keskinäiseen vuorovaikutukseen ja siinä välittyvään tukeen työpaikan kulttuurienvälisissä suhteissa, mutta se ei näyttäisi vaikuttavan tuen määrään johtaja-työntekijäsuhteessa. Olennaista Sayakcin (2007) tulosten perusteella on sosiaalisen tuen saaminen ylipäätään, mikä onkin yksi keskeisistä uuteen kulttuuriin sopeutumiseen liittyvistä haasteista. Vaikka sosiaalisella tuella näyttää olevan merkitystä yksilön ja organisaatioon suhteelle, se ei suoraan heijastu työn tuloksellisuuteen eikä selitä kovinkaan vahvasti esimerkiksi työssä syntyviä tunteita. Schmisseurin (2003) tutkimus osoitti, että johtajalta ja kollegoilta saatu tuki kyllä välittää työtyytyväisyyden ja työssä koetun emotionaalisen dissonanssin yhteyttä opetustyössä, mutta tuki ei ole vahvasti yhteydessä työn aiheuttaman emotionaalisen dissonanssin vaihteluun sinänsä. Meyersin ja 
Hearnin (2007) tulosten mukaan etätyön itsearvioitua tuloksellisuutta selittää paremmin pystyvyyden tunne kuin sosiaalinen tuki tai muut kollegiaaliseen viestintään liittyvät tekijät. Gibsonin ja Gibbsin (2005) tulosten perusteella supportiivisella viestintäilmastolla oli merkitystä hajautetun tiimin innovatiivisuudelle vain sinä mielessä, että se auttoi hallitsemaan kansallisen diversiteetin mukanaan tuomien haasteita.

\section{Johtopäätöksiä}

Tämän artikkelin tavoitteena oli osoittaa, millä tavoin sosiaalista tukea työyhteisöissä on tutkittu 2000-luvulla ja mitä sosiaalisesta tuesta tällä hetkellä tiedetään kansainvälisen tutkimuskirjallisuuden perusteella. Tarkastelu rajattiin 2000-luvulla julkaistuun empiiriseen puheviestinnän tutkimukseen. Artikkelissa tarkasteltiin tutkimusten ongelmanasettelua, sosiaalisen tuen teoreettista ja operationaalista määrittelyä, tutkimusmenetelmiä ja aineistoja.

Tutkimustehtävien perusteella voi päätellä, että sosiaalista tukea on tutkittu useimmin joko yksilön työhön liittyvän kuormituksen tai organisaatioon liittyvien kognitioiden kuten organisaatioon identifioitumisen tai tyytyväisyyden näkökulmasta. Lisäksi on tarkasteltu sosiaalisen tuen merkitystä ammatillisen roolin rakentumiselle ja kuvattu tuen tarvetta, osoittamista ja saamista työyhteisössä tai työhön liittyvissä suhteissa. Sosiaalisen tuen rooli tutkimuksissa on selittävä, eikä tukea ole tarkasteltu tämän katsauksen aineistossa lainkaan riippuvana muuttujana. Ainoastaan Steinheider, Wuestewald ja Bayerl (2006) tarkastelivat sitä, miten johtamisjärjestelmän muutos muuttaa myös organisaation koettua supportiivisuutta, ja Hopkins (2001) tarkasteli johtajan auttamisasenteen merkitystä tuen hakemiselle. Havainto on mielenkiintoinen, mutta sen selittäminen on haastavaa. Yksi mahdollinen syy voi nousta tutkimusperinteestä. Koska tuen tutkiminen on lähtökohtaisesti ollut yhteydessä hyvinvointiin, on mahdollista, että myös työn kontekstissa sosiaalinen tuki nähdään puheviestinnänkin tutkimuksessa pikemminkin työhyvinvoinnin osa-alueena kuin itsenään kiinnostavana vuorovaikutusilmiönä.

Sosiaalista tukea on tutkimuksissa tarkasteltu sekä interpersonaalisen tason että organisaatiotason ilmiönä. Interpersonaalisella tasolla sosiaalista tukea on tarkasteltu johtajalta ja työtovereilta saatuna sosiaalisena tukena, organisaatiotasolla tukea on kuvattu supportiivisen viestintäilmapiirin ja organisaation havaitun supportiivisuuden käsitteillä. Interpersonaalisen ja organisaatiotason tuen välistä suhdetta ei kuitenkaan tämän katsauksen aineiston perusteella ole tutkittu. Missä määrin interpersonaalisessa viestinnässä toteutuva tuki ja organisaation koettu supportiivisuus selittävät toinen toisiaan, on kiinnostava tutkimuskysymys. Olisi tärkeää myös tarkastella sitä, kumpi konstruktioista selittää vahvemmin yksilön rooliin ja työperäiseen kuormittumiseen liittyviä tekijöitä tai yksilön ja organisaation väliseen suhteeseen liittyviä tekijöitä. Tämä edel- 
lyttää sekä käsitteiden ja käytettyjen mittareiden analyysiä että empiiristä tutkimusta.

Tutkimustulosten perusteella voi todeta, että työyhteisöstä saatavalla tuella on tärkeä merkitys sille, kuinka yksilö voi hallita työperäistä kuormitustaan. Erityisesti johtajalta saatu tuki vaikuttaa tehokkaalta työuupumuksen ehkäisemisessä, mutta myös työtovereilta saadulla tuella on merkitystä kuormituksen hallinnassa. Johtajan ja johtamisviestinnän rooli on nähty tärkeäksi myös niissä tutkimuksissa, joissa tarkastellaan organisaatioon kuulumista ja työtyytyväisyyttä. On kuitenkin syytä muistaa, että yksilön käsityksiin organisaatiosta vaikuttavat monet tekijät, jopa interpersonaalinen vuorovaikutus työn ulkopuolella (Roloff \& Fonner 2005). Kiinnostavaa, joskaan ei ehkä yllättävää, tuloksissa on, että tuki ei näytä juurikaan selittävän työskentelyn tuloksia eikä koettua tuloksellisuutta, joka kytkeytyy vahvemmin pystyvyyden tunteeseen (Meyers \& Hearn 2007).

Puolet tarkastelluista tutkimuksista perustui kvantitatiiviseen menetelmään, puolet menetelmätriangulaatioon tai laadulliseen menetelmään. Menetelmien moninaisuus mahdollistaa rikkaan ja monitahoisen kuvan saamisen tutkimuskohteesta. Toisaalta se kertoo myös hajanaisuudesta. Vaikka varsinkin työperäisen kuormituksen osalta tutkimustulokset ovat yhdensuuntaisia, johtopäätösten tekeminen ja tutkimustulosten vertailu on hankalaa, koska tutkimuksissa on käytetty useita erilaisia mittareita. Kiinnostavaa on, että vaikka useat kirjoittajat määrittelevät tuen ensisijaisesti epävarmuuden hallinnaksi, sama teoreettinen lähtökohta voi johtaa hyvinkin erilaisiin empiirisiin valintoihin. Juuri operationaalisten käsitteiden moninaisuus on tehnyt sosiaalisen tuen tutkimisesta ja tutkimustiedon käytöstä haastavaa myös muissa konteksteissa (esim. Mikkola 2006), ja näyttää siltä, että tutkimusalueella on tarvetta kehittää systemaattisesti välineitä mittaamaan erityisesti interpersonaalista tukea työssä ja työyhteisöissä.

Vaikka supportiivista viestintää on tutkittu runsaasti viime vuosien aikana, ei ainakaan vielä ole käytetty hyväksi tietoa tuen antajan motivaatiosta, supportiivisten sanomien tulkitsemiseen vaikuttavista tilannetekijöistä ja sanomien rakentumisesta tutkittaessa sosiaalista tukea työn kontekstissa. Ainoastaan kahdessa tutkimuksessa analysoitiin supportiivisia sanomia, toisessa analyysi oli aineistolähtöistä (Fay \& Kline 2008) ja toisessa sovellettiin Barbeen ja Cunnighamin (esim. 1995) jäsennystä lohdutus- ja ratkaisukeskeisestä tuesta. Sosiaalisen tuen tutkiminen työn kontekstissa näyttäkin nojaavan voimakkaasti kognitiiviseen perinteeseen (Burleson \& MacGeorge 2002). Jotta työssä ja työyhteisössä saatavaa tukea voitaisiin syvällisemmin ymmärtää vuorovaikutusilmiönä, olisi tärkeää tarkastella tukea myös viestintäkäyttäytymisen tasolla. Tähän on mahdollisuus soveltamalla sitä tutkimustietoa ja niitä menetelmiä, joita on kehitetty tarkasteltaessa sosiaalista tukea läheisissä vuorovaikutus- 
suhteissa. Soveltamisen tavoitteena tulee kuitenkin olla analyysimenetelmien kehittäminen juuri työyhteisön suhteiden tarkastelemiseen.

\section{Kirjallisuus}

Albrecht, T. L. \& Adelman, M. B. 1984. Social support and life stress. New directions for communication research. Human Communication Research $11,3-32$.

Albrecht, T. L. \& Adelman, M. B. 1987. Communicating social support: A theoretical perspective. Teoksessa T. L. Albrecht, \& M. B. Adelman (toim.) Communicating social support. Newbury Park: Sage, 18-39.

Albrecht, T. L. \& Goldsmith, D.J. 2003. Social support, social networks and health. Teoksessa T. L. Thompson, A. M. Dorsey, K. I. Miller \& R. Parrott (toim.) Handbook of health communication. Mahwah: Lawrence Erlbaum, 263-284.

Amason, P., Allen, M. W. \& Holmes, S. A. 1999. Social support and acculturative stress in the multicultural workplace. Journal of Applied Communication Research 27, 310-334.

Apker, J. \& Ray, E. B. 2003. Stress and social support in health care organizations. Teoksessa T. L. Thompson, A. M. Dorsey, K. I. Miller \& R. Parrott (toim.) Handbook of health communication. Mahwah: Lawrence Erlbaum, 347-368.

Barbee, A. P. \& Cunnigham, M. R. 1995. An experimental approach to social support communications: Interactive coping in close relationships. Teoksessa B. R. Burleson (toim.) Communication Yearbook 18. Thousand Oaks: Sage, 318-413.

Bingham, S. G. \& Battey, K. M. 2005. Communication of social support to sexual harassment victims: Professors' responses to a student's narrative of unwanted sexual attention. Communication Studies 56, 131-155.

Bodie, G. D., \& Burleson, B. R. 2008. Explaining variations in the effects of supportive messages: A dual-process framework. Teoksessa C. Beck (toim.) Communication Yearbook 32. New York: Routledge, 354-398.

Burleson, B., \& MacGeorge, E. 2002. Supportive communication. Teoksessa M. L. Knapp \& J. A. Daly (toim.) Handbook of interpersonal communication $3^{\text {rd }}$ ed. Thousand Oaks: Sage, 374-422.

Czech, K. \& Forward, G. L. 2007. Communicating leadership: Faculty perceptions of the department chair. Paper presented at National Communication Association Annual Convention. November 2007, Chicago, United States.

Eisenberger, R., Huntington, R., Hutchison, S. \& Sowa, D. 1986. Perceived organizational support. Journal of Applied Psychology 71, 500-507.

Ellis, B. H. \& Miller, K. I. 1994. Supportive communication among nurses: Effects on commitment, burnout, and retention. Health Communication 6, $77-96$. 
Fay, M. \& Kline, S. 2008. High intensity telecommuting and organizational identification: The value of informal communication. Paper presented at International Communication Association Annual Meeting. May 2008, Montreal, Canada.

Forward, G. I. 2000. Clergy stress and role metaphors: An exploratory study. Journal of Communication and Religion 23, 158-164.

Gibb, J. 1961. Defensive communication. Journal of Communication 11, 141-148.

Gibson, C. B. \& Gibbs, J. L. 2005. Unpacking the concept of virtuality: The role of supportive communication climate in facilitating team innovation. Paper presented at International Communication Association Annual Meeting. May 2005, New York, United States.

Gilligan, E. 2005. Social bonding among disparate newsworkers in a competitive newsroom. Paper presented at International Communication Association Annual Meeting. May 2005, New York, United States.

Gómez, L. F. 2009. Time to socialize. Journal of Business Communication 46, 179-207.

Greenberg, N., Thomas, S., Murphy, D. \& Dandeker, C. 2007. Occupational stress and job satisfaction in media personnel assigned to the Iraq war (2003). A qualitative study. Journalism Practice 1, 356-371.

Hoeven, C. \& De Jong, M. 2006. Organizational communication and burnout symptoms. Paper presented at International Communication Association Annual Meeting. June 2006, Dresden, Germany.

Hopkins, K. M. 2001. Manager intervention with troubled supervisors. Management Communication Quarterly 15, 83-99.

Hullett, G. R., McMillan, J. J. \& Rogan, R. G. 2000. Caregivers' predispositions and perceived organizational expectations for the provision of social support to nursing home residents. Health Communication 12, 277-299.

Kleinman, S. S. 2000. Social identification in a computer-mediated group for women in science and engineering. Science Communication 21, 344-366.

Krouse, S. S. \& Afifi, T. D. 2007. Family-to-work spillover stress: Coping communicatively in the workplace. Journal of Family Communication 7 , $85-122$.

Meyers, N. \& Hearn, G. 2007. Communication issues and communicative self-efficacy for sustainable telework: An empirical study. Paper presented at International Communication Association Annual Meeting. May 2007, San Francisco, United States.

Mikkola, L. 2006. Tuen merkitykset potilaan ja hoitajan vuorovaikutuksessa. Jyväskylä Studies in Humanities 66. Jyväskylän yliopisto.

Omdahl, B. L. \& Fritz, J. M. H. 2006. Coping with problematic relationships in the workplace: Strategies that reduce burnout. Paper presented at International Communication Association Annual Meeting. June 2006, Dresden, Germany. 
Roloff, M. \& Brown, L. 2006. Organizational communication and burnout: The buffering role of perceived organizational support and psychological contract fulfillment as messages of employee value. Paper presented at International Communication Association Annual Meeting. June 2006, Dresden, Germany.

Roloff, M. \& Fonner, K. 2005. Exposure to downsizing and prospective employees' job expectations prior to organizational entry. Paper presented at International Communication Association Annual Meeting. May 2005, New York, United States.

Sand, G. \& Miyazaki, A. D. 2000. The impact of social support on salesperson burnout and burnout components. Psychology \& Marketing 17, 13-26.

Sayakci, A. 2007. How do voluntary sojourners adapt to new cultures? Common challenges that teachers and students face. Paper presented at National Communication Association Annual Convention. November 2007, Chicago, United States.

Schmisseur, A. 2003. The art of well-being: Managing emotional dissonance in the workplace. Paper presented at International Communication Association 2003 Annual Meeting. May 2003, San Diego, United States.

Singh, J. 2000. Performance productivity and quality of frontline employees in service organizations. Journal of Marketing 64, 15-34.

Steinheider, B., Wuestewald, T. \& Bayerl, P. 2006. The effects of participative management on employee commitment, productivity, and community satisfaction in a police agency. Paper presented at International Communication Association Annual Meeting. June 2006, Dresden, Germany.

Strauss, A. \& Corbin, J. 1990. Basics of qualitative research: Grounded theory procedures and techniques. Newbury Park: Sage.

Zhang, Q. \& Zhu, W. 2007. Teacher stress, burnout, and social support in Chinese secondary education. Human Communication 10, 487-496. 


\section{Liite 1.}

\begin{tabular}{|c|c|c|}
\hline \multicolumn{3}{|c|}{$\begin{array}{l}\text { Yksilön kuormitusta, työuupumusta ja selviytymistä } \\
\text { kuvaava ja selittävä tutkimus }\end{array}$} \\
\hline Tekijä & Tutkimustehtävä & $\begin{array}{l}\text { Sosiaalisen tuen teoreettinen } \\
\text { ja/tai operationaalinen käsite }\end{array}$ \\
\hline $\begin{array}{l}\text { Sand \& Miyazaki } \\
2000 \text { (A) }\end{array}$ & $\begin{array}{l}\text { Stressin hallinnan tavan, } \\
\text { tuen ja työuupumuksen } \\
\text { väliset yhteydet }\end{array}$ & $\begin{array}{l}\text { Organisaatiosta ja sen } \\
\text { ulkopuolelta saatu tuki }\end{array}$ \\
\hline Singh $2000(A)$ & $\begin{array}{l}\text { Työuupumuksen, tehtävään } \\
\text { liittyvän hallinnan, rooli- } \\
\text { stressin, koetun tulokselli- } \\
\text { suuden, organisaatioon } \\
\text { sitoutumisen ja tuen väliset } \\
\text { yhteydet }\end{array}$ & $\begin{array}{l}\text { Tuki selviytymisresurssina } \\
\text { Johtajalta saatu tuki }\end{array}$ \\
\hline $\begin{array}{l}\text { Greenberg, } \\
\text { Thomas, Murphy \& } \\
\text { Dandeker } 2003 \text { (A) }\end{array}$ & $\begin{array}{l}\text { Mediahenkilöstön kokema } \\
\text { ammatillinen stressi ja } \\
\text { työtyytyväisyys Irakin sodan } \\
\text { aikana }\end{array}$ & $\begin{array}{l}\text { Sosiaalisen tuen koettu } \\
\text { merkitys työhyvinvoinnille }\end{array}$ \\
\hline $\begin{array}{l}\text { Hoeven \& } \\
\text { De Jong } 2006(E)\end{array}$ & $\begin{array}{l}\text { Rahoitusneuvojien työuupu- } \\
\text { musta ennustavat tekijät }\end{array}$ & $\begin{array}{l}\text { Johtajalta ja työtovereilta } \\
\text { saatu tuki }\end{array}$ \\
\hline $\begin{array}{l}\text { Omdahl \& Fritz } \\
2006(E)\end{array}$ & $\begin{array}{l}\text { Työpaikan ongelmallisten } \\
\text { suhteiden ja työuupumuksen } \\
\text { välinen yhteys ja eri } \\
\text { selviytymisstrategioiden } \\
\text { tehokkuus }\end{array}$ & $\begin{array}{l}\text { Sosiaalisen tuen hakeminen } \\
\text { selviytymisstrategiana }\end{array}$ \\
\hline $\begin{array}{l}\text { Roloff \& Brown } \\
2006(E)\end{array}$ & $\begin{array}{l}\text { Organisaation koetun } \\
\text { supportiivisuuden ja psyko- } \\
\text { logisen sopimuksen yhteydet } \\
\text { työuupumukseen, työntekijän } \\
\text { sitoutumiseen ja ylitöihin }\end{array}$ & $\begin{array}{l}\text { Epävarmuuden hallinta } \\
\text { Organisaation koettu } \\
\text { supportiivisuus }\end{array}$ \\
\hline $\begin{array}{l}\text { Krouse \& Afifi } \\
2007 \text { (A) }\end{array}$ & $\begin{array}{l}\text { Perheeseen liittyvät stressi- } \\
\text { tekijät, stressin työpaikalle } \\
\text { leviämistä ehkäisevät selvi- } \\
\text { ytymiskeinot ja organisaation } \\
\text { supportiivista viestintää } \\
\text { edistävät tekijät }\end{array}$ & $\begin{array}{l}\text { Epävarmuuden hallinta } \\
\text { Johtajalta ja työtovereilta } \\
\text { saatu tuki } \\
\text { Aineistolähtöisesti luokitellut } \\
\text { tuen muodot }\end{array}$ \\
\hline $\begin{array}{l}\text { Zhang \& Zhu } \\
2007 \text { (A) }\end{array}$ & $\begin{array}{l}\text { Opettajien stressin ja } \\
\text { työuupumuksen välinen } \\
\text { suhde ja tuen suhde niihin }\end{array}$ & $\begin{array}{l}\text { Johtajalta, työtovereilta ja } \\
\text { läheisiltä saatu tuki } \\
\text { Emotionaalinen, tiedollinen } \\
\text { ja välineellinen tuki }\end{array}$ \\
\hline
\end{tabular}

(jatkuu) 


\begin{tabular}{|c|c|c|}
\hline \multicolumn{3}{|c|}{$\begin{array}{l}\text { Organisaatioon identifioitumista, tyytyväisyyttä } \\
\text { ja tuloksellisuutta selittävä ja kuvaava tutkimus }\end{array}$} \\
\hline Tekijä & Tutkimustehtävä & $\begin{array}{l}\text { Sosiaalisen tuen teoreettinen } \\
\text { ja/tai operationaalinen käsite }\end{array}$ \\
\hline $\begin{array}{l}\text { Gibson \& } \\
\text { Gibbs } \\
2005(E)\end{array}$ & $\begin{array}{l}\text { Supportiivisen viestintäilmaston } \\
\text { välilliset vaikutukset virtuaalisuudesta } \\
\text { johtuvien innovatiivisuutta ehkäi- } \\
\text { sevien haasteiden hallintaan }\end{array}$ & $\begin{array}{l}\text { Supportiivinen } \\
\text { viestintäilmasto }\end{array}$ \\
\hline $\begin{array}{l}\text { Gilligan } \\
2005(E)\end{array}$ & $\begin{array}{l}\text { Reporttereiden yhteistyö ja kilpailu } \\
\text { lehdistöhuoneessa }\end{array}$ & $\begin{array}{l}\text { Tuki sosiaalisen verkostoi- } \\
\text { tumisen ulottuvuutena }\end{array}$ \\
\hline $\begin{array}{l}\text { Roloff \& } \\
\text { Fonner } \\
2005(E)\end{array}$ & $\begin{array}{l}\text { Läheisten kanssa keskustelemisen } \\
\text { ja heiltä saadun emotionaalisen tuen } \\
\text { yhteys odotuksiin työpaikasta }\end{array}$ & $\begin{array}{l}\text { Epävarmuuden hallinta } \\
\text { Vanhemmilta ja ystäviltä } \\
\text { saatu tuki } \\
\text { Emotionaalinen tuki }\end{array}$ \\
\hline $\begin{array}{l}\text { Steinheider, } \\
\text { Wuestewald } \\
\text { \& Bayerl } \\
2006(E)\end{array}$ & $\begin{array}{l}\text { Osallistavan johtamisen merkitys } \\
\text { ja johtaja-työntekijäsuhteen laatu } \\
\text { poliisiorganisaatiossa }\end{array}$ & $\begin{array}{l}\text { Organisaation koettu } \\
\text { supportiivisuus }\end{array}$ \\
\hline $\begin{array}{l}\text { Czech \& } \\
\text { Forward } \\
2007(E)\end{array}$ & $\begin{array}{l}\text { Johtajan viestintäkäyttäytymisen } \\
\text { yhteys tehokkuuteen, viestintäilma- } \\
\text { piiriin, työ- ja suhdetyytyväisyyteen, } \\
\text { johtamistyyliin ja organisaatioon } \\
\text { sitoutumiseen }\end{array}$ & $\begin{array}{l}\text { Supportiivisen viestintä- } \\
\text { käyttäytymisen muodot }\end{array}$ \\
\hline $\begin{array}{l}\text { Meyers \& } \\
\text { Hearn } \\
2007(E)\end{array}$ & $\begin{array}{l}\text { Etätyölle merkityksellisten viestintä- } \\
\text { konstruktioiden tunnistaminen ja } \\
\text { niiden kyky ennustaa itsearvioitua } \\
\text { tuloksellisuutta }\end{array}$ & $\begin{array}{l}\text { Epävarmuuden hallinta } \\
\text { Johtajalta ja työtovereilta } \\
\text { saatu tuki }\end{array}$ \\
\hline $\begin{array}{l}\text { Fay \& Kline } \\
2008(E)\end{array}$ & $\begin{array}{l}\text { Epävirallisen viestinnän kuten } \\
\text { kollegiaalisen tuen ja kollegiaalisten } \\
\text { suhteiden laadun merkitys } \\
\text { organisaatioon identifioitumiselle }\end{array}$ & $\begin{array}{l}\text { Epävarmuuden hallinta } \\
\text { Supportiiviset sanomat }\end{array}$ \\
\hline $\begin{array}{l}\text { Goméz } \\
2009(A)\end{array}$ & $\begin{array}{l}\text { Organisaatioon sosiaalistumisen } \\
\text { ja organisaation aikakäsityksen } \\
\text { välinen suhde }\end{array}$ & $\begin{array}{l}\text { Supportiivinen viestintä- } \\
\text { käyttäytyminen uutta t } \\
\text { yöntekijää kohtaan }\end{array}$ \\
\hline
\end{tabular}


Liite 1. (jatkuu)

\begin{tabular}{|c|c|c|}
\hline \multicolumn{3}{|c|}{ Ammatillisen roolin rakentumista kuvaava tutkimus } \\
\hline Tekijä & Tutkimustehtävä & $\begin{array}{l}\text { Sosiaalisen tuen teoreettinen } \\
\text { ja/tai operationaalinen käsite }\end{array}$ \\
\hline $\begin{array}{l}\text { Forward } \\
2000(A)\end{array}$ & $\begin{array}{l}\text { Pastorin kokema stressin muoto ja } \\
\text { määrä, stressaavat tilanteet, } \\
\text { roolimetaforat ja roolin perustana } \\
\text { oleva informaatiolähde }\end{array}$ & $\begin{array}{l}\text { Epävarmuuden hallinta } \\
\text { Pastori tuen osoittajana ja } \\
\text { tarvitsijana }\end{array}$ \\
\hline $\begin{array}{l}\text { Hullett, } \\
\text { McMillan \& } \\
\text { Rogan } \\
2000 \text { (A) }\end{array}$ & $\begin{array}{l}\text { Roolistressi ja työuupumus, joka } \\
\text { perustuu omiin ja organisaation odo- } \\
\text { tuksiin sosiaalisen tuen osoittamisen } \\
\text { ensisijaisista muodoista hoitotyössä }\end{array}$ & $\begin{array}{l}\text { Emotionaalinen, käytännöl- } \\
\text { linen ja taloudellinen tuki, } \\
\text { suhteiden ylläpitäminen ja } \\
\text { ohjaaminen }\end{array}$ \\
\hline $\begin{array}{l}\text { Kleinman } \\
2000(A)\end{array}$ & $\begin{array}{l}\text { Naisten osallistuminen ja identifioitu- } \\
\text { minen ja tietokonevälitteiseen tuki- } \\
\text { ryhmään, osallistumisen tuoma hyöty }\end{array}$ & $\begin{array}{l}\text { Tuki verkkoyhteisöön kuulu- } \\
\text { misen syynä ja yhteisö } \\
\text { sosiaalisen tuen lähteenä }\end{array}$ \\
\hline $\begin{array}{l}\text { Schmisseur } \\
2003(E)\end{array}$ & $\begin{array}{l}\text { Sosiaalinen tuki ja rooli-identiteetti } \\
\text { välittävänä muuttujana yliopisto- } \\
\text { opettajien kokeman emotionaalisen } \\
\text { dissonanssin ja hyvinvoinnin välillä }\end{array}$ & $\begin{array}{l}\text { Epävarmuuden hallinta } \\
\text { Johtajalta ja työtovereilta } \\
\text { saatu tuki } \\
\text { Haettu ja pyytämättä saatu } \\
\text { tuki }\end{array}$ \\
\hline \multicolumn{3}{|c|}{ Tuen tarvetta, saamista ja osoittamista kuvaava tutkimus } \\
\hline Tekijä & Tutkimustehtävä & $\begin{array}{l}\text { Sosiaalisen tuen teoreettinen } \\
\text { ja/tai operationaalinen käsite }\end{array}$ \\
\hline $\begin{array}{l}\text { Amason, } \\
\text { Allen \& } \\
\text { Holmes } \\
1999 \text { (A) }\end{array}$ & $\begin{array}{l}\text { Latino- ja anglo-amerikkalaisten } \\
\text { työpaikalla kokema tuki ja sen } \\
\text { yhteys latinotaustaisten työn- } \\
\text { tekijöiden akkulturatiiviseen } \\
\text { stressiin }\end{array}$ & $\begin{array}{l}\text { Epävarmuuden hallinta } \\
\text { Johtajalta ja työtovereilta } \\
\text { saatu tuki } \\
\text { Tiedollinen, välineellinen, } \\
\text { emotionaalinen ja arviointituki }\end{array}$ \\
\hline $\begin{array}{l}\text { Hopkins } \\
2001(\mathrm{~A})\end{array}$ & $\begin{array}{l}\text { Keskijohdon ylemmältä johdolta ja } \\
\text { muista lähteistä saama ja hakema } \\
\text { tuki, osoitetun tuen muoto, käsitykset } \\
\text { johtajan suhtautumisesta apuun } \\
\text { ongelmatilanteessa }\end{array}$ & $\begin{array}{l}\text { Johtajalta saatu tuki ja } \\
\text { henkilökohtaisista lähteistä } \\
\text { saatu tuki }\end{array}$ \\
\hline $\begin{array}{l}\text { Bingham \& } \\
\text { Battey } \\
2005(A)\end{array}$ & $\begin{array}{l}\text { Professorin osoittama tuki } \\
\text { seksuaalista häirintää kokeneelle } \\
\text { opiskelijalle, tuen antajan ja saajan } \\
\text { sukupuolen ja tilannetekijöiden } \\
\text { merkitys supportiiviselle } \\
\text { viestintäkäyttäytymiselle }\end{array}$ & $\begin{array}{l}\text { Supportiiviset sanomat, } \\
\text { lohdutus- ja ratkaisu- } \\
\text { keskeinen tuki }\end{array}$ \\
\hline $\begin{array}{l}\text { Sayacki } \\
2007(E)\end{array}$ & $\begin{array}{l}\text { Opettajien ja opiskelijoiden kokemat } \\
\text { tyypilliset haasteet uuteen kulttuuriin } \\
\text { sopeutumisessa }\end{array}$ & $\begin{array}{l}\text { Tuen koettu merkitys } \\
\text { sopeutumisessa }\end{array}$ \\
\hline
\end{tabular}




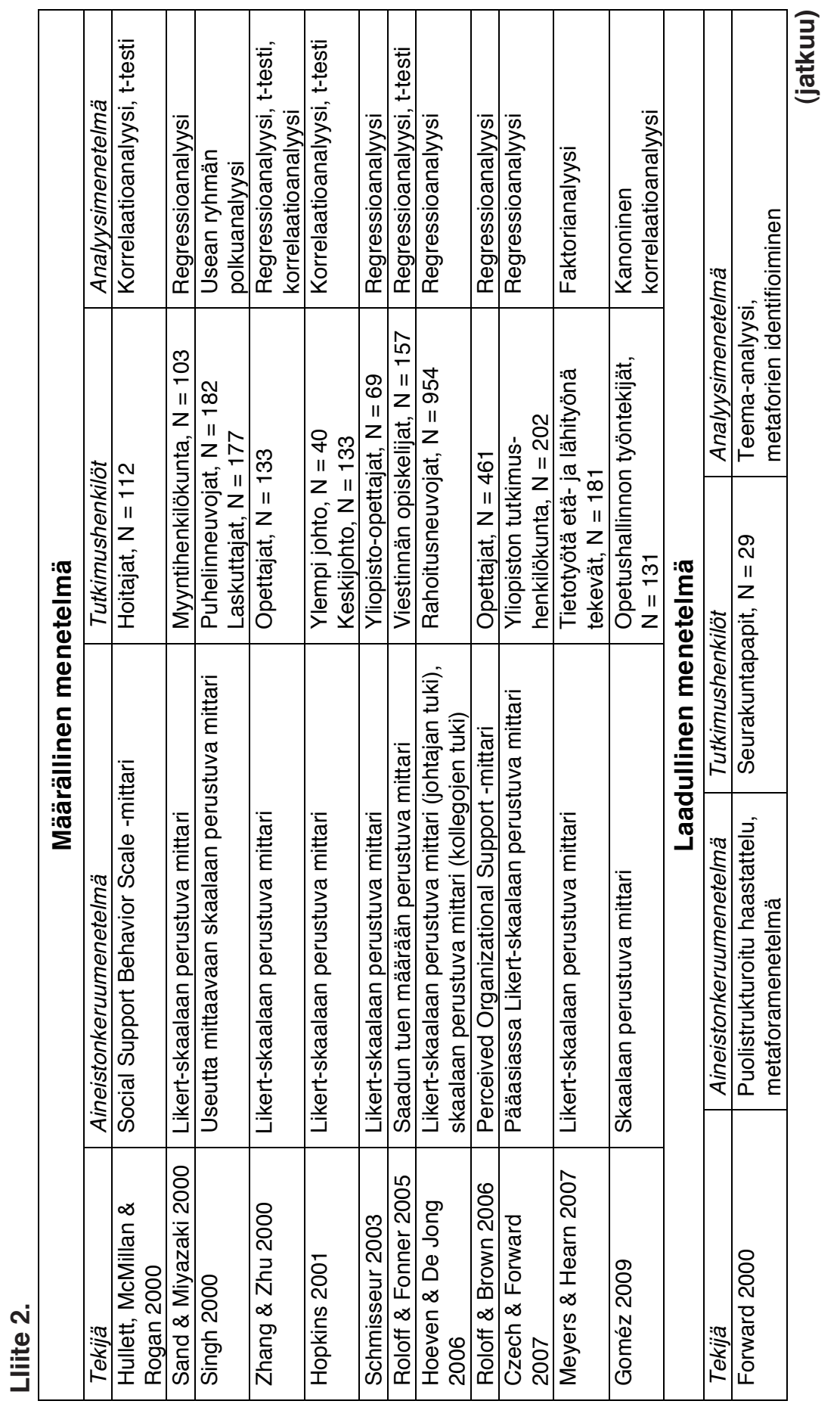




\begin{tabular}{|c|c|c|c|c|c|c|c|c|c|c|c|c|}
\hline 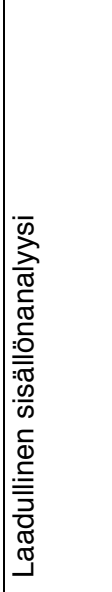 & 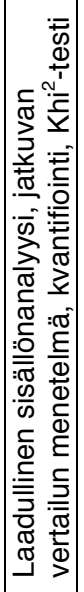 & 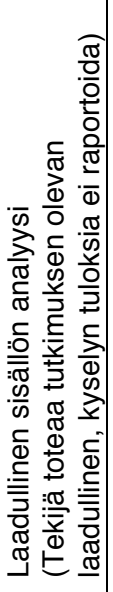 & 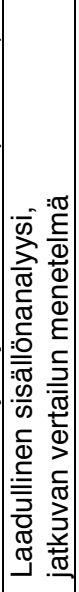 & 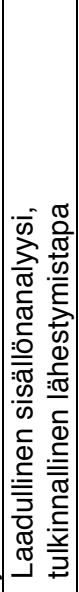 & \multirow{6}{*}{ 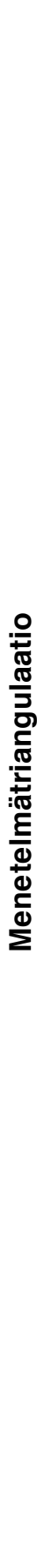 } & 童 & 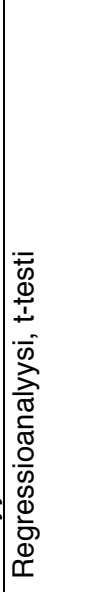 & 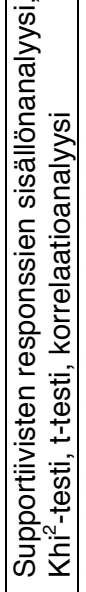 & 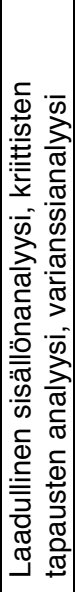 & 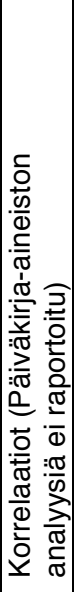 & 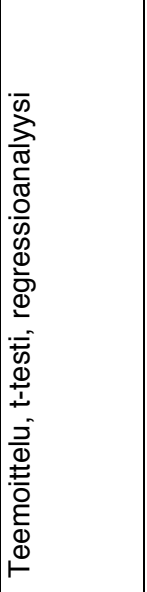 & 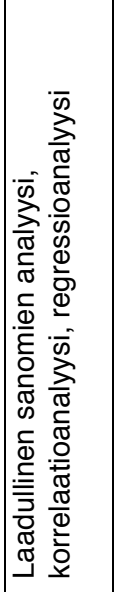 \\
\hline 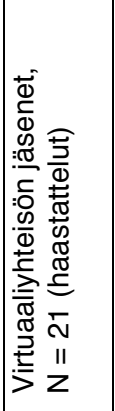 & 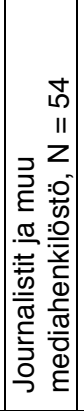 & 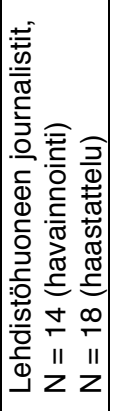 & 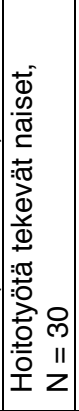 & 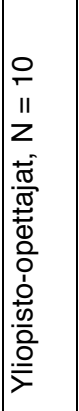 & & 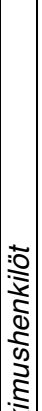 & 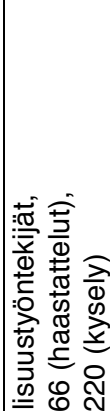 & $\left\{\begin{array}{l}0 \\
0 \\
11 \\
z \\
\vdots \\
\vdots \\
0 \\
0 \\
0 \\
0\end{array}\right.$ & 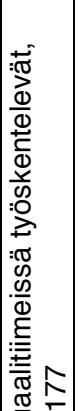 & 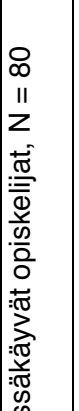 & 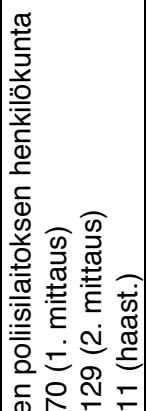 & 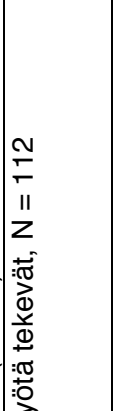 \\
\hline \multirow[b]{2}{*}{ 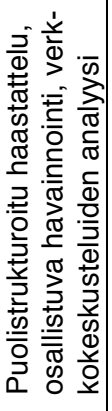 } & \multirow[b]{2}{*}{ 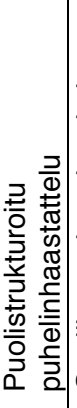 } & \multirow[b]{2}{*}{ 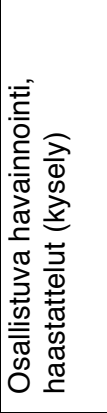 } & \multirow[b]{2}{*}{ 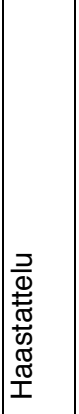 } & \multirow[b]{2}{*}{ 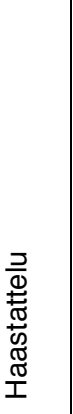 } & & & 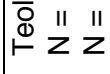 & 衣 & $\stackrel{?}{\stackrel{ \pm}{*}} \mathrm{II}$ & $\stackrel{0}{1}$ & $\begin{array}{llll}\frac{\sigma}{c} & \| & \| & \| \\
⿱ 亠 乂 & z & z & z\end{array}$ & : \\
\hline & & & & & & \multirow{2}{*}{ 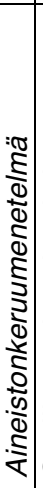 } & \multirow{2}{*}{ 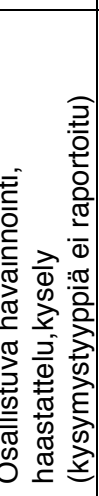 } & \multirow{2}{*}{ 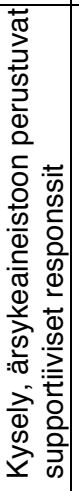 } & \multirow{2}{*}{ 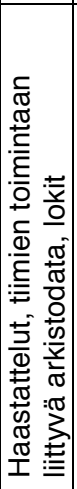 } & \multirow{2}{*}{ 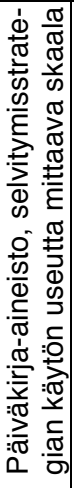 } & \multirow{2}{*}{ 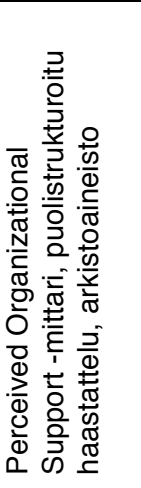 } & \multirow{2}{*}{ 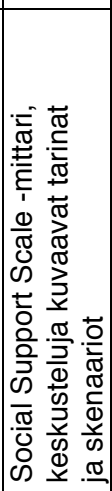 } \\
\hline \multirow[b]{2}{*}{ 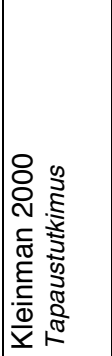 } & \multirow{2}{*}{ 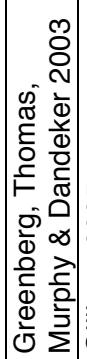 } & \multirow{2}{*}{ 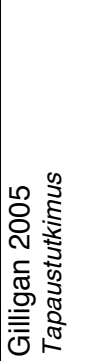 } & \multirow[b]{2}{*}{ 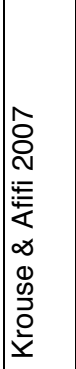 } & \multirow[b]{2}{*}{ 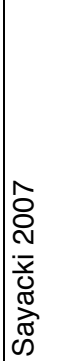 } & & & & & & & & \\
\hline & & & & & & & 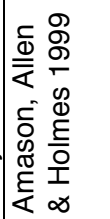 & 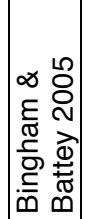 & 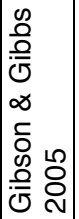 & 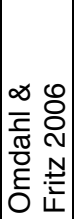 & 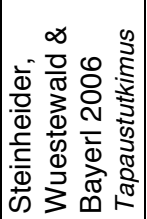 & 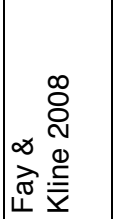 \\
\hline
\end{tabular}

